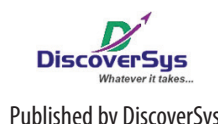

Published by DiscoverSys

\section{Association between transformational leadership, organizational commitments, and application of Total Quality Management (TQM) to employee performance in Sanglah General Hospital, Bali, Indonesia}

\author{
Fery Dwiyanto, ${ }^{1 *}$ I Putu Ganda Wijaya, ${ }^{2}$ Putu Ayu Indrayathi ${ }^{2}$
}

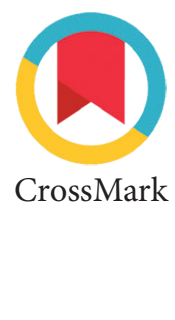

\title{
ABSTRACT
}

\begin{abstract}
Background: Employee performance results from work achieved by an employee in quality and quantity in carrying out tasks in accordance with the responsibilities given. Good employee performance increases hospital customer satisfaction. This study aims to determine the relationship between transformational leadership, organizational commitment, and the application of Total Quality Management (TQM) with employee performance at Sanglah Central General Hospital. Methods: A cross-sectional study was conducted among 87 samples. Samples in each installation/unit that fulfilled inclusion criteria were selected using proportional random sampling. Data were analyzed using univariate, bivariate (chi-square), and multivariate (logistic regression) by SPSS version 20 for Windows.

Results: Most employees perceived good in transformational leadership (67.8\%), good organization commitment (55.2\%), good
\end{abstract}

application of TQM (75.9\%), and good employee's performance (65.5\%). The bivariate analysis shows a significant association between transformational leadership ( $p=0.001)$, organization commitment $(p=0.001)$, and application of TQM $(p=0.010)$ with employees' performance in Sanglah General Hospital. However, according to the multivariate analysis, a statistically significant association variable is organizational commitment $(0 \mathrm{R}=547.96 ; 95 \% \mathrm{Cl}=4.922-613.673$; $\mathrm{p}=0.001$ ).

Conclusion: Factors associated with the employee's performance in Sanglah Hospital are transformational leadership, organizational commitment, and TQM. Therefore, stakeholders in the hospital should consider the loyalty of employees in determining policies to improve service quality continuously.

Keywords: Transformational Leadership, Organizational Commitment, Total Quality Management, Employee Performance. Cite This Article: Dwiyanto, F., Wijaya, I.P.G., Indrayathi, P.A. 2020. Association between transformational leadership, organizational commitments, and application of Total Quality Management (TQM) to employee performance in Sanglah General Hospital, Bali, Indonesia.Intisari Sains Medis 11(3): 928-933. DOI: 10.15562/ism.v11i3.821

'Regional Development Planning and Investment Agency, Bangli, Bali, Indonesia

${ }^{2}$ Department of Public Health and Preventive Medicine, Faculty of Medicine, Universitas Udayana, Bali, Indonesia
*Correspondence to: Fery Dwiyanto; Regional Development Planning and Investment Agency, Bangli, Bali, Indonesia;

ferydwiyanto@gmail.com

Received: 2019-09-04 Accepted: 2019-09-15 Published: 2020-09-24

\section{INTRODUCTION}

Sanglah General Hospital Denpasar continues to develop health services to meet the standards of the Joint Commission International (JCI), in 2013 was JCI accredited. Triennial JCI Accreditation Survey in March 2016, the findings were obtained more than the implementation of accreditation in 2013. The findings show that the leadership of Sanglah General Hospital has made policies to underlie the application of JCI accreditation standards (transformation of work culture). However, the implementation in the field is still not appropriate.

Most public services in health, especially hospitals in Indonesia, are still oriented to the organization and internal personal organization that causes patient dissatisfaction with the services provided. ${ }^{1}$ Employees who have high performance can support achieving goals and objectives set by an organization to improve employee performance is the primary concern of the leadership. ${ }^{2}$ Leadership style has a positive and significant effect on employee performance, and leadership style has a dominant influence on employee performance. ${ }^{3}$ One effort to improve employee performance is with organizational commitment. ${ }^{4}$ The level of leadership effectiveness can encourage and develop an organizational commitment to individuals. ${ }^{4}$ The application of good and effective leadership makes the level of employee loyalty increase and positively impacts the organizational commitment of employees. Employees who are committed to their work will have high performance. ${ }^{5}$

Based on the results of previous studies related to transformational leadership, organizational commitment, TQM, and its relationship with employee performance, no one has conducted analytical research on the association of transformational leadership, organizational commitment, and TQM to employee performance, especially in a government hospital institution with public service agency which is trying to improve the quality of 
their services towards a World Class Indonesian Hospital through JCI Accreditation. Therefore, researchers are interested in analyzing the association between transformational leadership, organizational commitment, and the application of TQM with employee performance at Sanglah Hospital, Denpasar.

\section{METHODS}

The quantitative research design used in this research is observational analytic by measuring using existing theories as a basis for empirical testing. This research was conducted at the Sanglah Central General Hospital in Denpasar, starting with submitting an Ethical Clearance to the Research Ethics Commission of the Faculty of Medicine, Udayana University/Sanglah General Hospital Denpasar in October 2017, which is approved at December $5^{\text {th }}, 2017$. Data collection using a questionnaire was carried out on December $2^{\text {nd }}, 2018$, simultaneously on 31 installations at the Sanglah Central General Hospital Denpasar.

Those included as research subjects in this study must meet the following inclusion criteria: Sanglah Hospital Denpasar employees with a minimum education are a high school or equivalent, Sanglah Denpasar Hospital employees who have been exposed to the implementation of TQM through JCI Accreditation at Sanglah Hospital Denpasar, Sanglah Hospital Denpasar employees who been working for more than 1 year.

Samples that were not included as research subjects were as follows: Sanglah Hospital Denpasar employees with contract and honorarium employment status as well as who refused to sign the informed consent. A Proportional Random Sampling was used as a sampling technique to provide opportunities for all members of the population to be sampled. The number of samples in this study was 87 samples. The type of data in this study is classified as primary data. These primary data are collected or derived from filling out questionnaires by respondents to obtain information about social characteristics, transformational leadership, organizational commitment, TQM implementation, and employee performance. The research instrument used in the form of a structured questionnaire containing a list of questions to measure the independent variables and the dependent variable. The independent variable consists of several lists of positive and negative questions about transformational leadership variables (7 positive questions and 1 negative question), organizational commitment variables ( 4 positive questions and 2 negative questions), and TQM implementation variables (19 positive questions and 1 negative question). The dependent variable contains questions related to employee performance (12 positive questions and 4 negative questions). Data were analyzed by SPSS version 20 for Windows.

\section{RESULTS}

Most of the respondents were female (65.5\%), followed by $36-45$ years of age group $(36.8 \%)$, bachelor's degree $(47.1 \%)$, and $\geq 5$ years length of works $(96.6 \%)$ (Table 1). Based on the main variables assessed in this study, most of the respondents were

\section{Table 1 The baseline characteristics of respondents}

\begin{tabular}{lcc}
\hline Characteristics & $\begin{array}{c}\text { Frequency } \\
(\mathrm{N}=87)\end{array}$ & $\begin{array}{c}\text { Percentage } \\
(\%)\end{array}$ \\
\hline
\end{tabular}

Sex

Male $\quad 30 \quad 34.5$

$\begin{array}{lll}\text { Female } & 57 & 65.5\end{array}$

Age (Years)

$17-25$

26-35

36-45

36.8

46-55

35.6

$56-65$

7

8.0

Education (Degree)

High School

18.4

Diploma

27.6

Bachelor

47.1

Master

6.9

Length of Works

(Years)

$\begin{array}{lcc}<5 & 3 & 3.4 \\ \geq 5 & 84 & 96.6\end{array}$

Transformational

Leadership

Good

59

67,8

Not Good

28

32,2

Organizational

Commitment

High

48

55,2

Low

39

TQM Implementation

$\begin{array}{lll}\text { Good } & 66 & 75,9 \\ \text { Not Good } & 21 & 24,1\end{array}$

Employee

Performance

Good

Not Good

30 
Table 2 The multivariate analysis of transformational leadership, organizational commitment, and the implementation of TQM with employee performance

\begin{tabular}{lccccc}
\hline & & & & \multicolumn{2}{c}{$\mathbf{9 5 \%} \mathbf{C l}$} \\
\cline { 5 - 6 } Variables & SE & P & Exp(B) & Lower & Upper \\
\hline Transformational Leadership & 0.784 & 0.566 & 1.568 & 0.337 & 7.292 \\
Organization Commitment & 1.231 & 0.001 & 54.962 & 6.922 & 0.610 \\
TQM Implementation & 0.741 & 0.196 & 0.196 & 11.157 \\
\hline
\end{tabular}

good in the transformational leadership $(67.8 \%)$, high organizational commitment (55.2\%), good TQM implementation (75.9\%), and good employee performance (65.5\%) (Table 1).

In multivariate analysis model using logistic regression test, the recent findings suggest that Organization Commitment was the most statistically significant variable related to the employee performance $(\mathrm{OR}=54.962 ; 95 \% \mathrm{CI}=4.922-613.673$; $\mathrm{p}=0.001)$, compared with transformational leadership $\quad(\mathrm{OR}=1.568 ; \quad 95 \% \mathrm{CI}=0.337-7.292$; $\mathrm{p}=0.566)$ or $\mathrm{TQM}$ implementation $(\mathrm{OR}=0.196$; 95\% CI $=0.610-11.157 ; \mathrm{p}=0.196)$ at Sanglah General Hospital, Bali, Indonesia (Table 2).

\section{DISCUSSION}

The results showed that the individual influence sub variable was more dominant compared to the others as much as $60.9 \%$ of respondents stated that the behavior of the leader is a role model at work, not only giving orders but giving examples and understanding work problems.

Leaders who pay attention to their subordinates, share the risk of using power if necessary, and do not use it for personal gain will instill pride in their staff. ${ }^{6}$ Organizational commitment is an attitude that is reflected by Affective, Continuous, and Normative describes employee loyalty to the organization and a continuous process in which organizational members express their concern for the organization and its success and continuous progress. $^{7}$

The results showed that the description of affective commitment based on employee emotional attachment, identification, and involvement in the organization is more prominent than Continuous Commitment and Normative Commitment.

TQM as an effort to manage the organization as a whole and continuously which consists of ten main elements, namely: Focus on customers, obsession with quality, scientific approach, longterm commitment, teamwork, continuous system improvement, education and training, controlled freedom, and the involvement of employee empowerment. $^{8}$
The results showed that customer focus and unity of purpose were well implemented. The services provided at the Sanglah General Hospital in Denpasar always strive to satisfy the needs of patient consumers. If there are findings related to problems in customer service at the Sanglah General Hospital in Denpasar, improvements will be made immediately, and the changes will be sustainable. Every organizational effort is directed at the same goal, and employees are given equal opportunities to improve the quality and implementation of employee duties in providing significant services for improving the quality of the hospital. ${ }^{9}$

Employee performance is the work achieved by an employee in carrying out his duties in accordance with given responsibilities as measured through innovative behavior, taking the initiative, level of self-potential, time management, achieving work quantity and quality, self-ability to achieve goals, relationships with colleagues work and customers and knowledge of the company's products. ${ }^{10}$ The results showed that the sub-variable of innovative behavior stood out compared to other sub-variables. The individual's behavior to produce, introduce, and apply new things was well implemented. Respondents stated that they had made innovations in work that brought changes in the work unit and thought that innovative behavior was needed in the work unit.

The results of the first hypothesis test in this study indicate that there is a significant relationship between transformational leadership and employee performance. It increased transformational leadership that includes efforts to change towards improvement at Sanglah General Hospital, impacting employee performance. The results of this study, which explain that empirically transformational leadership has a positive and significant effect on employee performance, is in line with research conducted by previous studies., ${ }^{2,11,12}$

The independent variable of transformational leadership has a positive relationship with employee performance, which means that a leader is influential in transforming employee behavior into someone capable and highly motivated to increase work performance and quality, which ultimately 
the goals of the organization can be achieved. A transformational leadership is a leader with a desire to prioritize the interests of the organization and the interests of his subordinates rather than his own so that he can inspire his subordinates and is able to motivate his subordinates to improve their work methods and innovate by finding new ways to maximize the implementation of their duties. ${ }^{13}$ Transformational leadership specifically pay attention to and treat staffs and try to influence their staffs about the importance of values and beliefs, ideals, and values. ${ }^{13}$

The results of the second hypothesis test in this study indicate that there is an association between organizational commitment and employee performance. The higher the organizational commitment at the Sanglah General Hospital has a real impact on improving employee performance. This result is in accordance with the results of research conducted by another study, which explains that organizational commitment, especially affective commitment, and normative commitment, is significant with the readiness to change in employees. ${ }^{14}$ Nurjanah et al., states that organizational commitment has a positive and significant effect on employee performance. ${ }^{11}$ Organizational commitment is a relative strength of individual identification of their involvement in an organization. ${ }^{11,14}$ Organizational commitment shows an attitude that reflects employee loyalty to the organization and a continuous process in which organizational members express their concern for the organization and its success and continuous progress..$^{14}$ Employees committed to their organization will be more able to survive as part of the organization than members who are not committed to the organization. Organizational commitment is an active relationship between individuals and organizations where individuals are willing to give something of themselves to help the success and success of the organization and present something outside of loyalty to an organization. ${ }^{14}$

Based on the results of the study using the chi-square statistical test, it was found that there was a significant relationship between the role of TQM and performance. TQM is an approach taken by Sanglah Hospital to improve the quality of its services, reduce operational costs, and increase productivity. Other evidence also suggests that organizations that pursue TQM best practice can achieve higher returns and cash flows as well as greater shareholder value. ${ }^{16}$ The results of this study are consistent with a previous study by Chairany $\mathrm{N}$ and Lestari PW which stated that TQM has a positive and significant effect on employee performance. ${ }^{16}$

Total Quality Management (TQM) plays a significant role in increasing its competitiveness. ${ }^{17}$
Quality of service is also an essential element in addition to fast delivery (speed of delivery) for hospitals to compete (competition) in the global market that changes continuously. ${ }^{17}$ One form of best management practice in hospitals, in this case, TQM, is to emphasize the concept of achieving the overall quality within the organization. ${ }^{17}$ With the implementation of high TQM, the organization can achieve the predetermined work standards in terms of the quality and quantity of employee work to increase employee performance.

The results of the analysis show that the variable organizational commitment plays a significant role in the performance of employees at the Sanglah General Hospital. The employee performance elements consist of quantity, quality, cooperation, innovation, and employee independence. ${ }^{18}$ Subordinates feel trust, pride, loyalty, and respect for their superiors and the organization and are motivated by transformational leadership that makes them do more than expected. ${ }^{18}$ Implementing good and effective leadership makes the level of employee loyalty increase and has a positive impact on employee organizational commitment. The management system that involves all elements and aspects of the company is the concept of Total Quality Management (TQM), which has the aim of continuously optimizing the organization's capabilities and resources and increasing the quality of the resulting production so that it can survive and be able to compete with other organizations. The success of implementing TQM is that the organization is able to give full attention to employees so that they believe in the organization. ${ }^{16-18}$ This can foster a commitment to remain part of the organization and motivate employees to produce a better performance to create a strong organizational commitment. Organizational commitment is the level of trust and acceptance of labor towards organizational goals and a desire to remain in the organization. ${ }^{15}$ Employees who are committed to their work will have high performance. Commitment is an integration of feelings of love and loyalty from employees to their work or company. High commitment owned by employees will bind emotionally (affective), rational (normative), and have a longterm career desire (continuous) so that these factors can improve employee performance optimally. ${ }^{19}$ The analysis of the relationship between transformational leadership, organizational commitment, and TQM on employee performance at Sanglah General Hospital together shows that organizational commitment plays a significant role in achieving good employees perform. This study uses a leadership instrument with four indicators, organizational commitment using three indicators, and the application of TQM as many as six indicators. 
The variable data scale is nominal, so that accuracy is weak. This study did not analyze confounding variables, and questionnaires were distributed in a questionnaire. Researchers only describe the characteristics of respondents without analyzing the relationship between employee performance and respondent characteristics.

\section{CONCLUSION}

Based on the results of research and discussion on the analysis of the association between transformational leadership, organizational commitment, and the application of TQM with employee performance at Sanglah General Hospital, it can be concluded that there is an association between transformational leadership and employee performance, between organizational commitment and employee performance, between the implementation of TQM and the performance of employees and the dominant factor associated to employee performance is an organizational commitment at Sanglah Hospital, Denpasar.

\section{ACKNOWLEDGMENT}

Chancellor of Udayana University, Director of the Postgraduate Program at Udayana University and Head of the Master of Public Health Science Study Program, Postgraduate Program at Udayana University for the opportunity given to the author to attend and complete the education.

President Director of the Sanglah Denpasar General Hospital, who has supported and granted permission for the research to be carried out, as well as research respondents who have participated in this research. My beloved wife and children who always provide support and enthusiasm.

\section{CONFLICT OF INTEREST}

There is no competing interest regarding the manuscript.

\section{ETHICS CONSIDERATION}

Ethics approval has been obtained from the Ethics Committee, Faculty of Medicine, Universitas Udayana, Bali, Indonesia prior to the study being conducted.

\section{FUNDING}

None.

\section{AUTHOR CONTRIBUTION}

All of authors are equally contribute to the study from the conceptual framework, data gathering, data analysis, until reporting the results of study through publication.

\section{REFERENCES}

1. Ekawati FM, Claramita M, Hort K, Furler J, Licqurish S, Gunn J. Patients' experience of using primary care services in the context of Indonesian universal health coverage reforms. Asia Pac Fam Med. 2017;16:4.

2. Mamesah, Kusmaningtyas A. Pengaruh Gaya Kepemimpinan Transformasional dan Transaksional terhadap Kepuasan Karyawan dan Dampaknya terhadap Kinerja Karyawan. Jurnal Akutansi, Manajemen Bisnis dan Sektor Publik (JAMBSP). 2009;5(3):349-368.

3. Gemeda HK, Lee J. Leadership styles, work engagement and outcomes among information and communications technology professionals: A cross-national study. Heliyon. 2020;6(4):e03699.

4. Mosadeghrad AM, Ferdosi M. Leadership, job satisfaction and organizational commitment in healthcare sector: proposing and testing a model. Mater Sociomed. 2013;25(2):121-126.

5. Li C, Naz S, Khan MAS, Kusi B, Murad M. An empirical investigation on the relationship between a highperformance work system and employee performance: measuring a mediation model through partial least squares-structural equation modeling. Psychol Res Behav Manag. 2019;12:397-416.

6. Al-Habib NMI. Leadership and organizational performance: Is it essential in healthcare systems improvement? A review of literature. Saudi J Anaesth. 2020;14(1):69-76.

7. Allen NJ, Meyer JP. Affective, Continuance, and Normative Commitment to the Organization: An Examination of Construct Validity. J Vocat Behav. 1996;49(3):252-276.

8. Alzoubi MM, Hayati KS, Rosliza AM, Ahmad AA, AlHamdan ZM. Total quality management in the healthcare context: integrating the literature and directing future research. Risk Manag Healthc Policy. 2019;12:167-177.

9. Yank G. Quality improvement in health care organizations: a general systems perspective. Behav Sci. 1995;40(2):85103. doi: 10.1002/bs.3830400202

10. McConnell CR. Managing employee performance. Health Care Manag (Frederick). 2004;23(3):273-283.

11. Nurjanah, Djastuti I, Ratnawati I. Pengaruh Gaya Kepemimpinan dan Budaya Organisasi terhadap Komitmen Organisasi dalam Meningkatkan Kinerja Karyawan (Studi Pada Biro Lingkup Departemen Pertanian) [Tesis]. Program Studi Magister Manajemen Program Pasca sarjana Universitas Diponegoro. 2008.

12. Tian H, Iqbal S, Akhtar S, Qalati SA, Anwar F, Khan MAS. The Impact of Transformational Leadership on Employee Retention: Mediation and Moderation Through Organizational Citizenship Behavior and Communication. Front Psychol. 2020;11:314.

13. Thomson NB 3rd, Rawson JV, Slade CP, Bledsoe M. Transformation and Transformational Leadership: A Review of the Current and Relevant Literature for Academic Radiologists. Acad Radiol. 2016;23(5):592-599.

14. Shore LM, Wayne SJ. Commitment and employee behavior: comparison of affective commitment and continuance commitment with perceived organizational support. J Appl Psychol. 1993;78(5):774-780.

15. Corbett, Lawrence M, Kate N. Rastrick. Quality performance and Organizational Culture: A New Zealand Study. International Journal of Quality \& Reliability Management. 2000;17(1):14-26. 
16. Chairany N, Lestari PW. Pengaruh TQM terhadap Kinerja Perusahaan melalui Kepemimpinan serta Perilaku Produktif Karyawan [Skripsi]. Universitas Hasanuddin Makassar. 2011.

17. Sila I, Ebrahimpour M. An investigation of the total quality management survey based research published between 1989 and 2000: A literature review. International Journal of Quality \& Reliability Management. 2002;19(7):902-970.

18. Leitão J, Pereira D, Gonçalves Â. Quality of Work Life and Organizational Performance: Workers' Feelings of Contributing, or Not, to the Organization's Productivity. Int J Environ Res Public Health. 2019;16(20):3803.
19. Ćulibrk J, Delić M, Mitrović S, Ćulibrk D. Job Satisfaction, Organizational Commitment and Job Involvement: The Mediating Role of Job Involvement. Front Psychol. 2018;9:132.

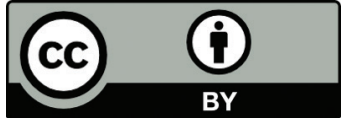

This work is licensed under a Creative Commons Attribution 